\title{
Synergistic antitumor activity of oridonin and arsenic trioxide on hepatocellular carcinoma cells
}

\author{
GUO CHEN $^{1}$, KE WANG $^{1}$, BING-YA YANG $^{1}$, BO TANG $^{1,2}$, JIAN-XIANG CHEN $^{1}$ and ZI-CHUN HUA ${ }^{1,2}$ \\ ${ }^{1}$ The State Key Laboratory of Pharmaceutical Biotechnology and Department of Biochemistry, College of Life Sciences, \\ Nanjing University, Nanjing 210093; ${ }^{2}$ Changzhou High-Tech Research Institute of Nanjing University \\ and Changzhou TargetPharma Laboratories Inc., Changzhou 213164, P.R. China
}

Received July 6, 2011; Accepted August 16, 2011

DOI: $10.3892 /$ ijo.2011.1210

\begin{abstract}
Although arsenic trioxide $\left(\mathrm{As}_{2} \mathrm{O}_{3}\right)$ has been successfully employed in treatment of patients with APL (acute promyelocytic leukemia), the sensitivity of solid tumor cells to this treatment was much lower than APL cells. The single agent of $\mathrm{As}_{2} \mathrm{O}_{3}$ was inefficient for treatment of hepatocellular carcinoma (HCC) in phase II trial demonstrating that new modalities of treatment with enhanced therapeutic effect are needed. In this study, we showed that oridonin, a diterpenoid isolated from traditional Chinese medicine Rabdosia rubescences, greatly potentiated apoptosis induced by $\mathrm{As}_{2} \mathrm{O}_{3}$ in hepatocellular carcinoma cells. The synergistic pro-apoptosis effect of combination of these two drugs led to increase in intracellular reactive oxygen species (ROS) level and N-acetyl-L-cysteine (NAC), a thiolcontaining anti-oxidant, was able to completely block the effect. The combination treatment induced ROS-dependent decrease in mitochondrial membrane potential (MMP) decrease, and relocation of Bax and cytochrome $\mathrm{C}$. Besides, oridonin dramatically increased the intracellular $\mathrm{Ca}^{2+}$ overload triggered by $\mathrm{As}_{2} \mathrm{O}_{3}$. Furthermore, the co-treatment of oridonin and $\mathrm{As}_{2} \mathrm{O}_{3}$ induced ROS-mediated down-regulation of Akt and XIAP, and inhibition of NF- $\kappa \mathrm{B}$ activation. The two drug combination enhanced tumor suppression activity in murine HCC model compared with single agent treatment in vivo. These findings demonstrate that oridonin can sensitize hepatocellular carcinoma cells to $\mathrm{As}_{2} \mathrm{O}_{3}$ treatment and will facilitate the optimization of $\mathrm{As}_{2} \mathrm{O}_{3}$ therapy for $\mathrm{HCC}$ patients.
\end{abstract}

\section{Introduction}

Hepatocellular carcinoma (HCC) is one of the most common cancers in the world. Surgery is curative in only a minority of patients due to coexisting advanced cirrhosis, multifocal

Correspondence to: Dr Zi-Chun Hua, The State Key Laboratory of Pharmaceutical Biotechnology, Nanjing University, 22 Hankou Road, Nanjing 210093, P.R. China

E-mail: zchua@nju.edu.cn

Key words: oridonin, arsenic trioxide, apoptosis, hepatocellular carcinoma, reactive oxygen species disease, invasion and extrahepatic metastases (1). Although locoregional treatments have been shown to be somewhat effective, their therapeutic efficiency based on highly selected patients, possibly limiting its generalizability to other patients with different clinical profiles. Thus, systemic chemotherapy remains the main options for the majority of HCC patients with unresectable tumors (2). Various clinical trials have reported that the response rates of single-agent chemotherapy for patients with unresectable HCC vary from 0 to $20 \%$. Combination chemotherapy including doxorubicin, cisplatin, fluorouracil and interferon, has been studied and the results have yielded more effectiveness than those found for single agents (3).

Arsenic trioxide $\left(\mathrm{As}_{2} \mathrm{O}_{3}\right)$, a traditional Chinese medicine, has been widely employed to treat APL (acute promyelocytic leukemia). It is well established that $\mathrm{As}_{2} \mathrm{O}_{3}$ induces complete remissions in approximately $80-90 \%$ of patients diagnosed with APL, as well as $60-90 \%$ of all-trans-retinoic acid (ATRA)refractory patients (4-6). Besides APL cells, $\mathrm{As}_{2} \mathrm{O}_{3}$ also induced apoptosis of a variety of solid tumor cell lines including hepatocellular (7) gastric (8) esophageal (9) prostate (10) colorectal cancers (11). However, the anti-tumor efficacy of $\mathrm{As}_{2} \mathrm{O}_{3}$ against solid tumors has not been as good as APL. It requires much higher dosages to inhibit solid cancer growth than those required to inhibit hematologic malignancies. The high dosage of $\mathrm{As}_{2} \mathrm{O}_{3}$ could cause adverse effects such as leukopenia, anemia, fever, vomiting and the dose-limiting toxicity is the main hindrance for its application in solid cancers (12). Although, extensive studies have been demonstrated that $\mathrm{As}_{2} \mathrm{O}_{3}$ could induce hepatocellular tumor growth inhibition and cells apoptosis $(7,13)$, single-agent arsenic trioxide was not active against advanced $\mathrm{HCC}$ at the dosages of $0.16-0.24 \mathrm{mg} / \mathrm{kg}$ per day in a phage II trial (12). Thus, new strategies of treatment with enhanced therapeutic effect and alleviated toxicity are needed for application of $\mathrm{As}_{2} \mathrm{O}_{3}$ on patients with HCC.

Oridonin is a diterpene compound extracted from the plant isodon rubescens which has been used as anti-inflammation and anti-tumor agent in traditional Chinese medicine for thousands of years. Oridonin has been shown to possess cell cycle arrest, apoptosis and autophagy-inducing activities towards a variety of cancer cells (14). Besides, oridonin is able to trigger ROS generation and perturb redox balance in hepatocellular carcinoma cells (15). An important event during treatment of cancer cells with $\mathrm{As}_{2} \mathrm{O}_{3}$ involves the generation of reactive 
oxygen species (ROS), and elevation of the cellular ROS could facilitate $\mathrm{As}_{2} \mathrm{O}_{3}$-induced apoptosis $(16,17)$. In this study, we aimed to verify our hypothesis that oridonin could improve the anti-tumor efficacy and reduce the adverse effects of $\mathrm{As}_{2} \mathrm{O}_{3}$ for treatment of HCC.

\section{Materials and methods}

Cell lines and reagents. Human hepatocellular cancer cell lines Bel7402, SMMC7721, HepaG2 and murine hepatoma cell line Hepa1-6 were routinely grown in Dulbecco's modified Eagle's medium (DMEM) supplemented with $10 \%$ fetal bovine serum and incubated at $37^{\circ} \mathrm{C}$ in $5 \% \mathrm{CO}_{2} . \mathrm{As}_{2} \mathrm{O}_{3}$ was purchased from Sigma (St. Louis, MO, USA) and oridonin was obtained from Biopurify (Cheng Du, China).

Cell viability assay. Cells were seeded in 96-well plates at $5 \times 10^{3}$ cells per well and exposed to agents for $48 \mathrm{~h}$. After treatment, the MTT assay was performed. Absorbance at $570 \mathrm{~nm}$ was directly proportional to the number of living cells in culture.

Apoptosis assessment. Apoptosis was detected by annexin V/ propidium iodide (PI) double stain and terminal deoxynucleotidyl transferase dUTP nick-end labeling (TUNEL) assay. The annexin V/PI stain was performed as previously described (18). Briefly, Bel7402 cells were stained with EGFP-tagged annexin $\mathrm{V}$ for 20 min post-treatment, then PI was added. The stained cells were analyzed by flow cytometry. TUNEL analysis was performed using DNA fragmentation detection kit following the manufacturer's instructions (Merck Chemicals, Germany). The number of TUNEL positive cells in the field at magnifications $\mathrm{x} 200$ was quantified.

Western blotting. After treatment, Bel7402 cells were harvested and lysed. Extracted proteins were separated on SDS-PAGE and then transferred onto PVDF membranes. After blocking in 5\% milk, the membranes were firstly hybridized with primary antibody, and then with a horseradish peroxidase-conjugated secondary antibody (Santa Cruz, USA). The Western blots were detected using enhanced chemiluminescence sytem (Amersham Pharmacia Biotech, USA). The mitochondria and cytoplasm fractions were extracted using the mitochondria extraction kit (Beyotime, China).

ROS detection and intracellular glutathione (GSH) measurement. 2,7-Dichlorodihydrofluorescein diacetate (DCF-DA) (Invitrogen, USA) was used to detect intracellular ROS level. DCF-DA is intracellularly cleaved by non-specific esterases and oxidized by ROS to the fluorescent 2,7-dichlorofluorescein (DCF). After washing once with PBS, treated cells were incubated with $20 \mu \mathrm{M}$ DCF-DA in serum-free DMEM at $37^{\circ} \mathrm{C}$ for $30 \mathrm{~min}$, then detected by flow cytometry. Cellular GSH levels were analyzed using 5-chloromethylfluorescein diacetate (CMFDA) (Invitrogen). CMFDA is converted to fluorescent 5-chloromethylfluorescein (CMF) by cytoplasmic esterases and then reacted with glutathione. Cells were incubated with $5 \mu \mathrm{M} \mathrm{CMFDA}$ at $37^{\circ} \mathrm{C}$ for 30 min after washed once with PBS, then $1 \mu \mathrm{g} / \mathrm{ml}$ PI was added to stain the dead cells before analyzing by flow cytometry.
Measurement of mitochondrial membrane potential and cytosolic $\mathrm{Ca}^{2+}$. Mitochondrial membrane potential was measured using 3,3'-dihexyloxacarbocyanine iodide [DiOC6(3)] (Invitrogen). Briefly, cells were washed once with ice-cold PBS after treatment and then incubated with $50 \mathrm{nM}$ DiOC6(3) in serum-free DMEM for $30 \mathrm{~min}$ in $5 \% \mathrm{CO}_{2}$ at $37^{\circ} \mathrm{C}$, and then analyzed by flow cytometry. For detection of cytosolic $\mathrm{Ca}^{2+}$, cells after treatment were washed once with PBS and then incubated in serum-free DMEM containing $2 \mu \mathrm{M}$ fluo-4 acetoxymethylester (AM) (Invitrogen) for $30 \mathrm{~min}$ in $5 \% \mathrm{CO}_{2}$ at $37^{\circ} \mathrm{C}$. The cells were left at room temperature for $15 \mathrm{~min}$ and then analyzed.

Luciferase assay. Bel 7402 cells were transiently transfected with NF- $\mathrm{KB}$ luciferase reporter plasmid (Stratagene, USA) using Lipofectamine $2000^{\mathrm{TM}}$ (Invitrogen) according to the manufacturer's instruction. Twelve hours post transfection, cells were treated with $8 \mu \mathrm{M} \mathrm{As}_{2} \mathrm{O}_{3}, 5 \mu \mathrm{g} / \mathrm{ml}$ oridonin, their combination, the combination plus $2.5 \mathrm{mM}$ NAC or $0.5 \mu \mathrm{M}$ PMA (as positive control) for $24 \mathrm{~h}$. Luciferase activity was then measured by the Dual Luciferase Reporter Assay system (Promega, USA).

Tumor implantation and evaluation of antitumor effects in vivo. 6 to 8-week old female C57BL/6 mice were implanted subcutaneously (s.c) on the mid-right side with $1 \times 10^{7}$ Hepa 1-6 mouse hepatoma cells in $0.1 \mathrm{ml}$ PBS. After the tumors reached the size of $\sim 0.1 \mathrm{~cm}^{3}$, mice were randomized into four groups with 7 mice per group. Group I received $3 \mathrm{mg} / \mathrm{kg} \mathrm{As} \mathrm{O}_{3}$ in $0.2 \mathrm{ml}$ of $0.9 \% \mathrm{NaCl}$ solution, group II received equal volume of oridonin at dose of $10 \mathrm{mg} / \mathrm{kg}$, Group III received $3 \mathrm{mg} / \mathrm{kg} \mathrm{As}_{2} \mathrm{O}_{3}$ plus $10 \mathrm{mg} / \mathrm{kg}$ oridonin respectively, Group IV received $0.2 \mathrm{ml}$ $0.9 \% \mathrm{NaCl}$ solution as control. Mice were administered drugs intraperitoneally (i.p.) daily with an interval once every 6 times. Tumor volumes were measured at the 0 and 3 weeks after administration and determined using the formula: tumor volume $=$ length $\mathrm{x}$ width ${ }^{2} \mathrm{x} 0.52$ (19). The animal study protocol was in according with the guideline of administration of lab animals issued by the Ministry of Science and Technology (Benjing, China) and approved by the Jiangsu Institutional Animal Care and Use Committee (IACUC).

Statistical analysis. Quantitative data were expressed as mean \pm standard deviation (SD) and analyzed using SPSS software. Paired Student's t-test was performed to assess statistical significance. Differences between experimental groups were considered significant at $\mathrm{p}<0.05$.

\section{Results}

Synergistic inhibition of oridonin and $\mathrm{As}_{2} \mathrm{O}_{3}$ on hepatic carcinoma cell growth. Various doses of oridonin were used in combination with $\mathrm{As}_{2} \mathrm{O}_{3}$ in human hepatic carcinoma cell lines including Bel7402, HepaG2, SMMC7721, and murine Hepa 1-6 cells. Compared with treatment of $\mathrm{As}_{2} \mathrm{O}_{3}$ alone, combined treatment with oridonin induced significant decreases of cells viability (Fig. 1). For Bel7402, treated with low dose $(6 \mu \mathrm{g} / \mathrm{ml})$ of oridonin alone reduced cell growth by $\sim 5 \%$. When this dose of oridonin was combined with $6 \mu \mathrm{M} \mathrm{As}_{2} \mathrm{O}_{3}$ the reduction in growth was $70 \%$ (Fig. 1A). Besides, similar treatment causes no synergic effect on non-malignant $293 \mathrm{~T}$ (human embryonic kidney cell line) cells (data not shown). 
A

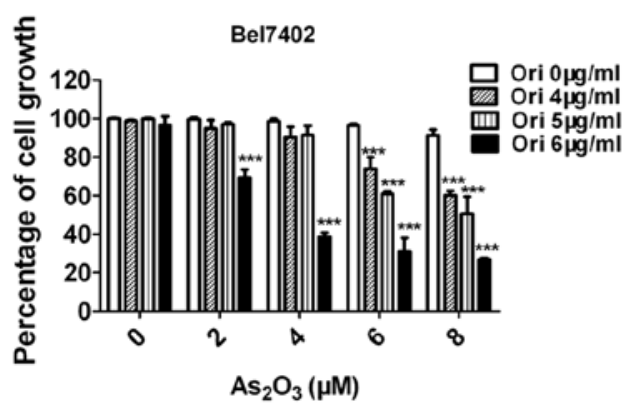

C

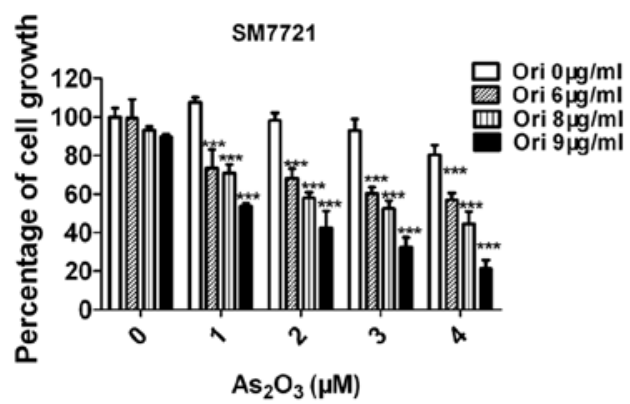

B

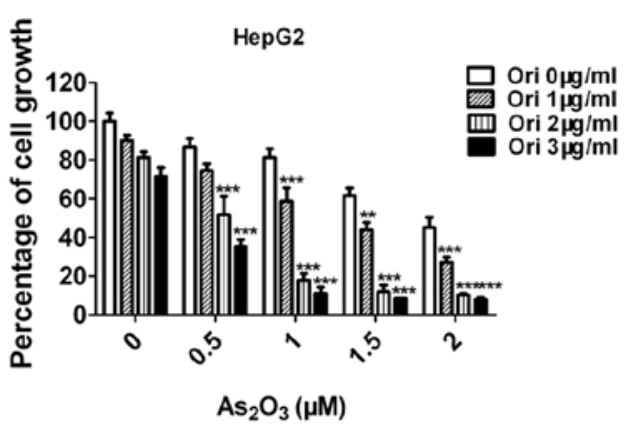

D

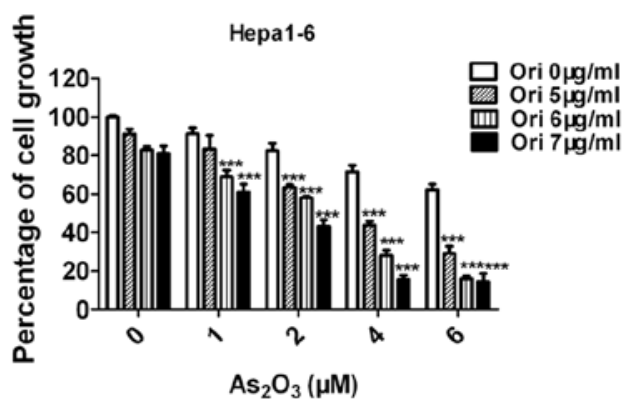

Figure 1. Cell viability assay. Human hepatocarcinoma cells Bel7402 (A), HepG2 (B), SM7721 (C) and mouse hepatocarcinoma cells Hepa1-6 (D) were co-treated with the indicated concentrations of $\mathrm{As}_{2} \mathrm{O}_{3}$ and oridonin (ori) for $48 \mathrm{~h}$. Cell number was determined by the absorbance at $570 \mathrm{~nm}$ and expressed as a percent of control cells. Representative experiments, $\mathrm{n}=3$, mean $\pm \mathrm{SD}$. ${ }^{* *} \mathrm{p}<0.01 ;{ }^{* * *} \mathrm{p}<0.001$ when compared with $0 \mu \mathrm{g} / \mathrm{ml}$ oridonin (ori $0 \mu \mathrm{g} / \mathrm{ml}$, white bar).

Oridonin-enhanced apoptosis induced by $\mathrm{As}_{2} \mathrm{O}_{3}$. To examine the apoptosis of Bel7402 cells treated with low dose of oridonin, $\mathrm{As}_{2} \mathrm{O}_{3}$ and their combination, annexin V/PI stain and terminal deoxynucleotidyl transferase dUTP nick-end labeling (TUNEL) assay were performed. As shown in Fig. 2A-D, though $5 \mu \mathrm{g} / \mathrm{ml}$ oridonin caused no apoptosis, it significantly potentiated $\mathrm{As}_{2} \mathrm{O}_{3}$ induced apoptosis. $\mathrm{As}_{2} \mathrm{O}_{3}$ at dose of $8 \mu \mathrm{M}$ alone induced slight apoptosis $(\sim 10 \%)$ at $48 \mathrm{~h}$, when it combined with oridonin, apoptosis was greatly enhanced, up to $\sim 35 \%$ (Fig. 2B). Antioxidization agent NAC could completely blocked this synergistic pro-apoptosis effect of the two-drug combination (Fig. 2A-D), which indicates that intracellular ROS play a critical role in the induction of apoptosis.

Caspases are essential components of mammalian apoptosis machinery, their activation level directly reflects the extent of apoptosis. During intrinsic apoptosis, procaspase 9 is cleaved into an active caspase, which in turn cleaves downstream pro-caspase 3 into an executor. Active caspase 3 cleaves many substrates such as poly (ADP)-ribose polymerase (PARP) (20). As shown in Fig. 2E, procaspase 3, procaspase 9, and PARP were significantly cleaved in the co-treatment of oridonin and $\mathrm{As}_{2} \mathrm{O}_{3}$, but cleavage of procaspase 3 and PARP were hardly detected in any single agent treatment.

Oridonin elicits elevation of cellular ROS level. We next assessed the ROS production in the variously treated Bel7402 cells using DCFDA fluorescence dye. As shown in Fig. 3A and B, exposure of cells to comparatively low concentration of $\mathrm{As}_{2} \mathrm{O}_{3}(8 \mu \mathrm{M})$ hardly elicited any elevation of cellular ROS level. But low dose of oridonin alone $(5 \mu \mathrm{g} / \mathrm{ml})$ induced remarkable ROS level elevation and co-treatment with oridonin and $\mathrm{As}_{2} \mathrm{O}_{3}$ dramatically augmented this ROS level elevation.
Glutathione (GSH) is a major cellular reductant and has been shown to be crucial for regulation of cell proliferation, cell cycle progression and apoptosis (21). So, we analyzed the GSH level by using CMF fluorescence whose intensity is proportional to the intracellular GSH level. As shown in Fig. 3C and D, one population of CMF fluorescence negative cells $(\sim 20 \%)$ were induced by comparably low dose of oridonin, which indicated that treatment with oridonin caused depletion of cellular GSH. Besides, combination of oridonin and $\mathrm{As}_{2} \mathrm{O}_{3}$ decreased further the GSH level $(\sim 30 \%)$. Treatment with $8 \mu \mathrm{M} \mathrm{As} \mathrm{A}_{2}$ alone causes no obvious depletion of GSH when compared with control. In addition, in combination treatment of oridonin and $\mathrm{As}_{2} \mathrm{O}_{3}$, the negative $\mathrm{CMF}$ fluorescence cells partly showed PI positive staining $(\sim 10 \%)$ (Fig. 3E), which indicated that some cells showing GSH depletion were not viable. Although oridonin alone decreased GSH level, the PI staining mostly was negative, these data indicated that oridonin alone could not induce cell death.

Co-treatment with oridonin and $\mathrm{As}_{2} \mathrm{O}_{3}$ causes accelerated loss of mitochondrial membrane potential. Excessive ROS production may decrease in the mitochondrial membrane potential and impairment of the mitochondrial respiratory chain (22). We used DiOC6(3) to measure the mitochondrial membrane potential. As shown in Fig. 4A and B, the two-drug combination caused much more reduction of DiOC6 fluorescence compared with single agent treatment. This indicates that the effect of oridonin in enhancing $\mathrm{As}_{2} \mathrm{O}_{3}$ induced apoptosis involves mitochondrial damage. Loss of mitochondrial membrane potential resulted in release of cytochrome $\mathrm{C}$ from mitochondrial to cytosol and initiates apoptosis. As expected, co-treatment with oridonin and $\mathrm{As}_{2} \mathrm{O}_{3}$ caused cytochrome $\mathrm{C}$ release, and this relocation was inhibited by NAC (Fig. 4C). 

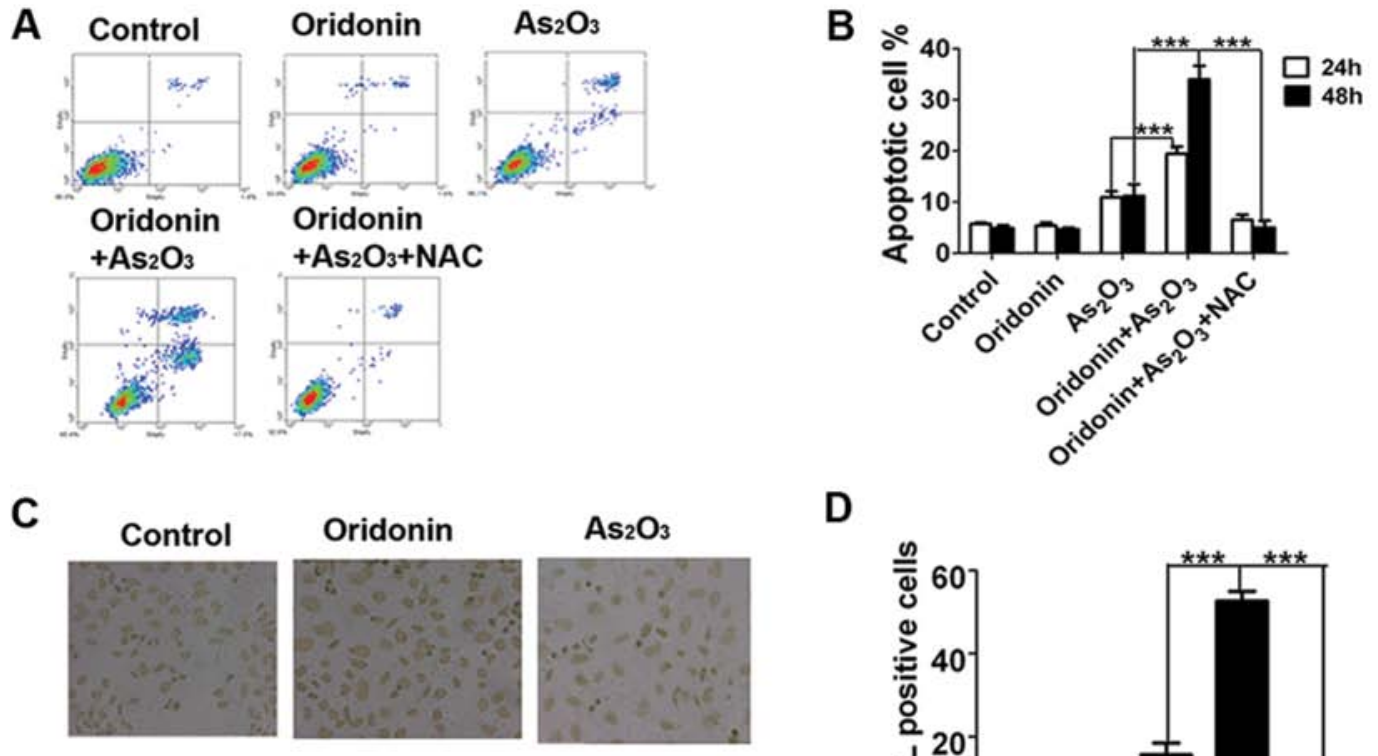

D

Oridonin $+\mathrm{As}_{2} \mathrm{O}_{3}$ Oridonin $+\mathrm{As}_{2} \mathrm{O}_{3}+\mathrm{NAC}$
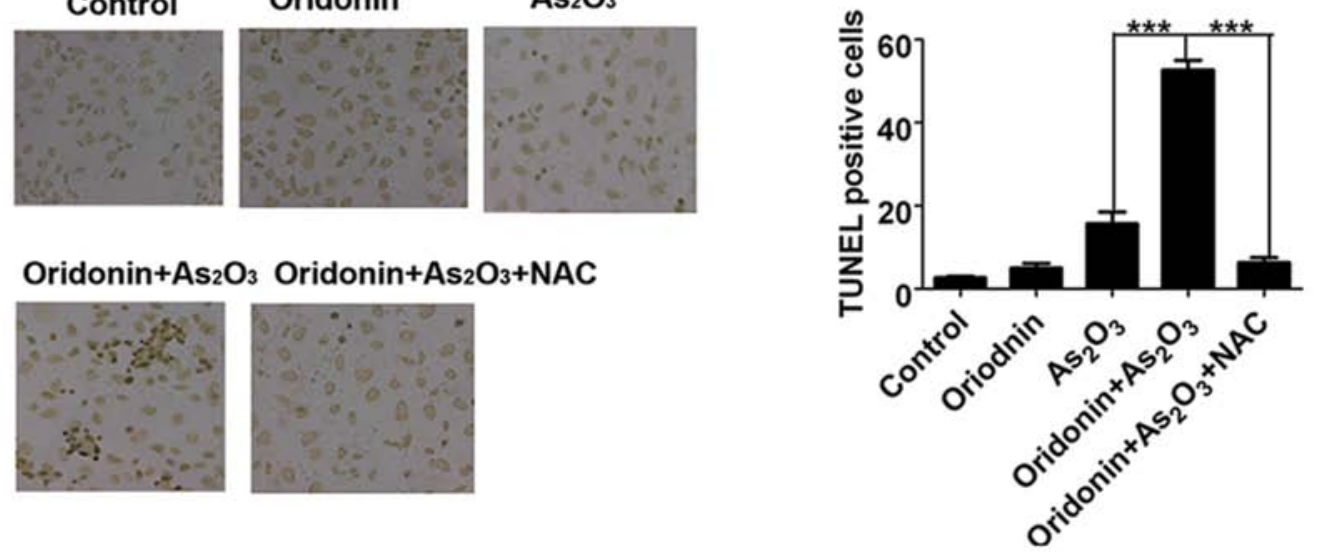

E

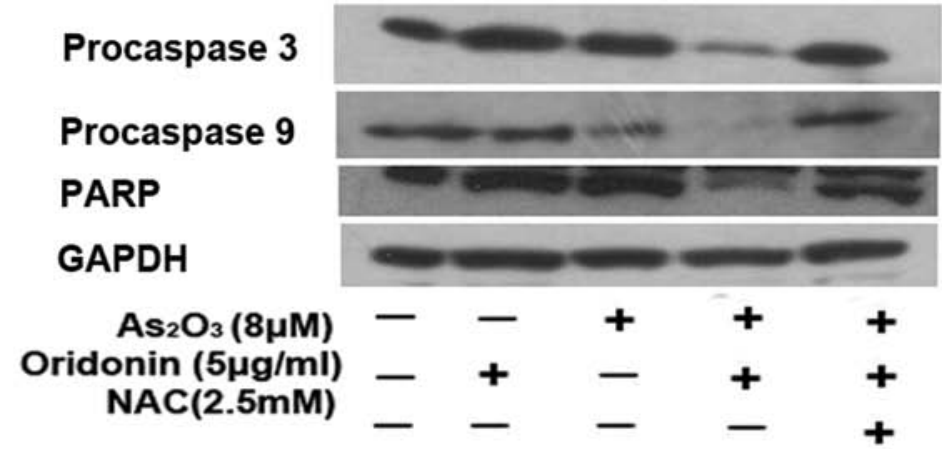

Figure 2. Apoptosis analysis by annexin V/PI stains (A and B) and TdT-mediated dUTP nick-end labeling (TUNEL) assays (C and D). Bel7402 cells were treated with $5 \mu \mathrm{g} / \mathrm{ml}$ oridonin, $8 \mu \mathrm{M} \mathrm{As}_{2} \mathrm{O}_{3}$, the combination of two drugs, or the combination of two drugs plus $2.5 \mathrm{mM} \mathrm{NAC}$ for 24 or $48 \mathrm{~h}$. Annexin V/PI stains was analyzed by flow cytometry, density plots for 48 -h treatment (A) and the percentage of annexin V positive cells was counted (B). Cells treated as mentioned above for $24 \mathrm{~h}$ were fixed for TUNEL assay as described in Materials and methods. Detection by microscope magnification x200) (C), the number of TUNEL positive cells was quantified (D). Representative experiments, $n=3$, mean \pm SD. ${ }^{* * *} \mathrm{p}<0.001$. (E) Cleavage of procaspase 3, procaspase 9 and PARP. After treatment, Bel7402 cells were lysed and subjected to Western blot analysis.

It has been shown that translocation of Bax from cytosol to mitochondrial could cause loss of mitochondrial membrane potential (23). We investigated whether the combination of oridonin and $\mathrm{As}_{2} \mathrm{O}_{3}$ induces translocation of Bax. As shown in Fig. $4 \mathrm{C}$, co-treatment with oridonin and $\mathrm{As}_{2} \mathrm{O}_{3}$ caused remarkable increase of $\mathrm{Bax}$ in mitochondria and reduction in the cytosol.

Because excessive ROS could damage cellular components and trigger intracellular $\mathrm{Ca}^{2+}$ overload (24), we used Fluo4 to monitor intracellular $\mathrm{Ca}^{2+}$ level. As shown in Fig. 4D and E, treatment with $\mathrm{As}_{2} \mathrm{O}_{3}$ alone increased the intracellular $\mathrm{Ca}^{2+}$ level and oridonin enhanced $\mathrm{As}_{2} \mathrm{O}_{3}$-induced intracellular $\mathrm{Ca}^{2+}$ overload. Although it has been known that elevation of cyto- solic-free calcium concentration could play a role as a signal for the activation of apoptosis, pre-treatment of Bel7402 cells with $25 \mu \mathrm{M}$ BAPTA/AM, an intracellular calcium chelator, could not block this synergistic cytotoxicity induced by combination of $\mathrm{As}_{2} \mathrm{O}_{3}$ and oridonin (data not shown).

Enhanced activation of MAPKs by co-treatment with oridonin and $\mathrm{As}_{2} \mathrm{O}_{3}$. Mitogen-activated protein kinases (MAPKs) are activated by a wide variety of cellular stimuli and involved in the regulation of most cellular processes. To investigate a potential involvement of MAPKs in combination treatment induced cell death, we analyzed the activation status of p38, ERK, JNK. As shown in Fig. 5, combination treatment of cells with oridonin and 
A

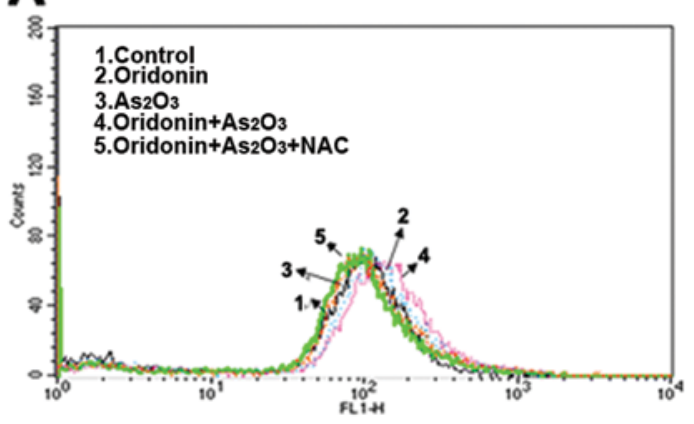

C

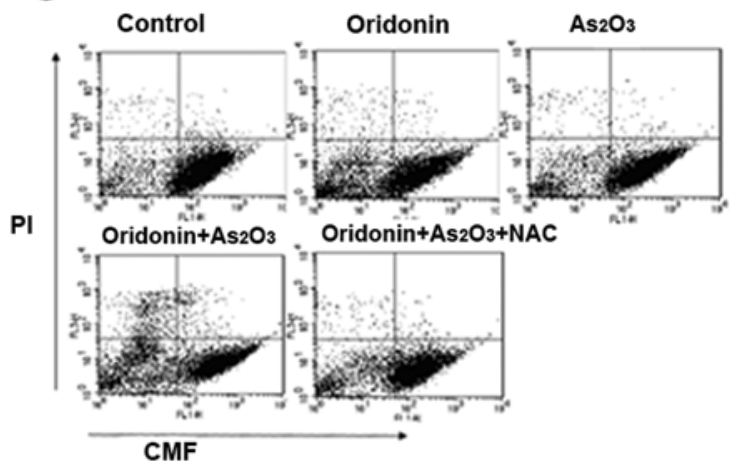

B
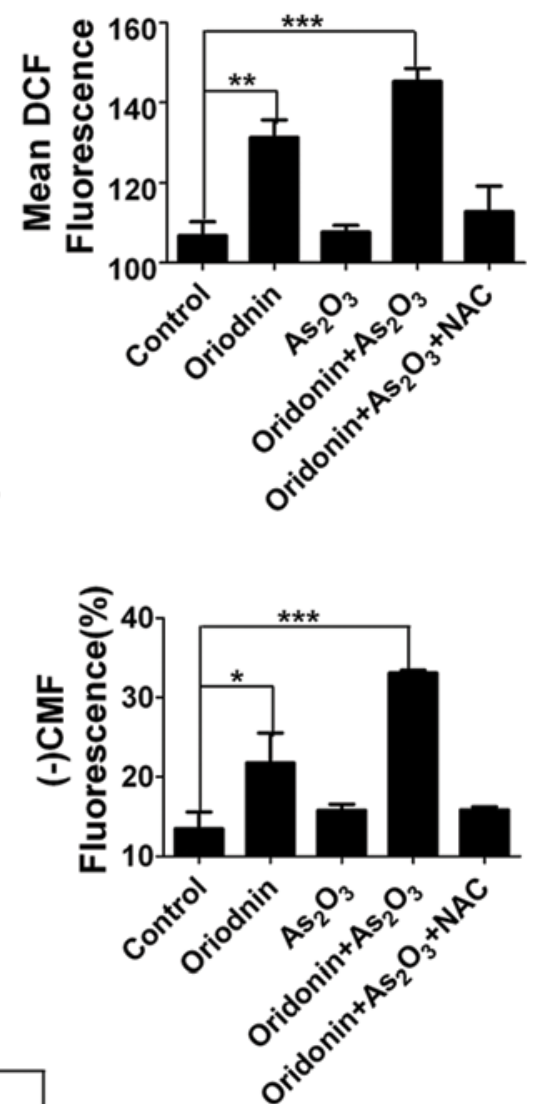

$\mathbf{E}$

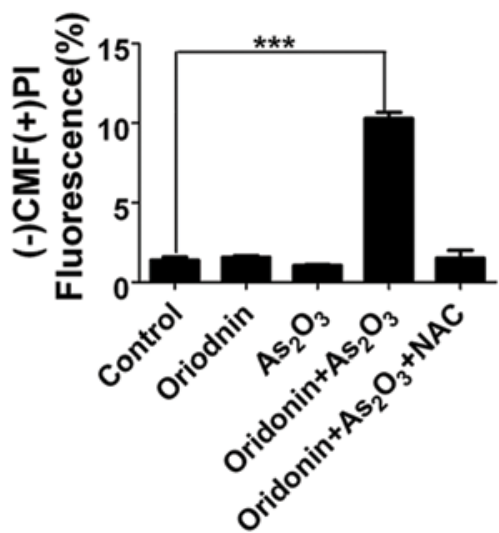

Figure 3. Detection of intracellular ROS and GSH level. Bel7402 cells were treated with $5 \mu \mathrm{g} / \mathrm{ml} \mathrm{oridonin}, 8 \mu \mathrm{M} \mathrm{As}_{2} \mathrm{O}_{3}$, the two-drug combination, or the combination plus $2.5 \mathrm{mM}$ NAC for $20 \mathrm{~h}$. DCF fluorescence was measured by flow cytometry (A) and the mean fluorescence of DCF is shown (B). CMF and PI double staining was analyzed by flow cytometry in dot plots (C). The percentage of CMF fluorescence negative cells (D) and CMF fluorescence negative and PI fluorescence positive cells (E) are shown. Representative experiments, $\mathrm{n}=3$, mean \pm SD. ${ }^{*} \mathrm{p}<0.05 ;{ }^{* *} \mathrm{p}<0.01 ;{ }^{* * *} \mathrm{p}<0.001$.

$\mathrm{As}_{2} \mathrm{O}_{3}$ resulted in dramatic increase of the phosphorylated form of p38, ERK1, JNK1/2, and the activation of these kinases could be blocked by the anti-oxidization agent NAC. These results suggested that combination treatment with oridonin and $\mathrm{As}_{2} \mathrm{O}_{3}$ induced ROS stress-dependent MAPKs activation. Pre-treatment of cells with SB203580, SP600125, U0126, respectively as p38, JNK, ERK specific inhibitor, failed to shown any obvious changes in combination treatment-induced cytotoxicity effects (data not shown).

Inhibition of Akt, XIAP expression and $N F-\kappa B$ activity. To explore pro-survival signaling pathways in this combination strategy, we investigated akt, X-linked inhibitor of apoptosis (XIAP) expression and NF- $\kappa \mathrm{B}$ activity in Bel7402 cells. As shown in Fig. 6A, co-treatment with oridonin and $\mathrm{As}_{2} \mathrm{O}_{3}$ significantly decreased Akt, X-linked inhibitor of apoptosis (XIAP) expression and NAC could also block this effect. Besides, Akt phosphorylation ( $\mathrm{p}-\mathrm{Akt}$ ) which represents the activated form was not detected in Bel7402 cells (data not shown). The activation of $\mathrm{NF}-\kappa \mathrm{B}$ was evaluated using $\mathrm{NF}-\kappa \mathrm{B}$ driven luciferase reporter assay and co-treatment with oridonin and $\mathrm{As}_{2} \mathrm{O}_{3}$ significantly reduced the activity of $\mathrm{NF}-\kappa \mathrm{B}$ compared with administration of $\mathrm{As}_{2} \mathrm{O}_{3}$ alone (Fig. 6B).

Enhanced antitumor activity in vivo of the two-drug combination. To evaluate the anti-tumor efficacy in vivo, we used the subcutaneous murine hepa1-6 tumor model and intraperitoneal administration of drugs $\left(3 \mathrm{mg} / \mathrm{kg} \mathrm{As}_{2} \mathrm{O}_{3}, 10 \mathrm{mg} / \mathrm{kg}\right.$ oridonin or 

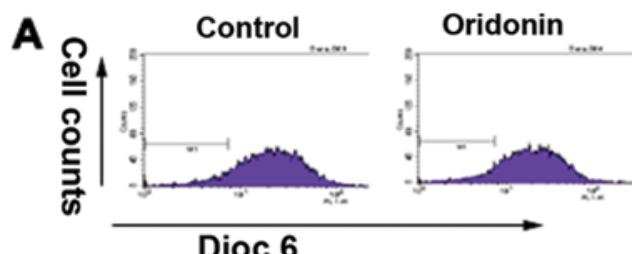

B

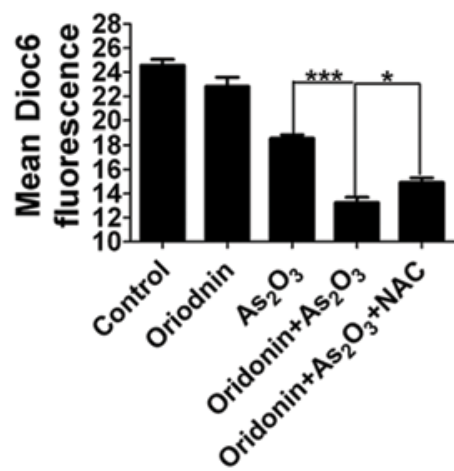

D

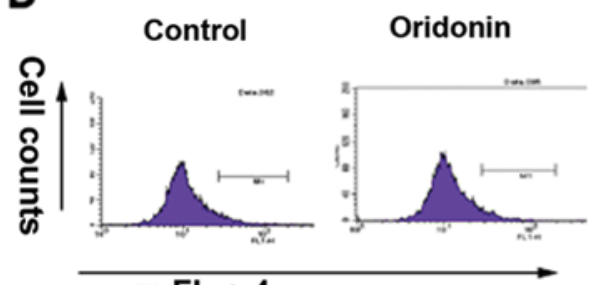

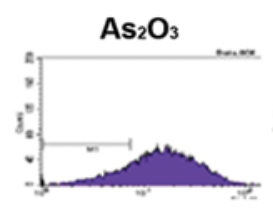
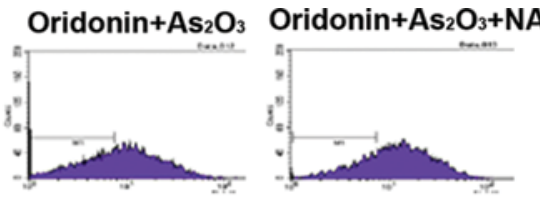

C

Cytochrome C

Bax

GAPDH

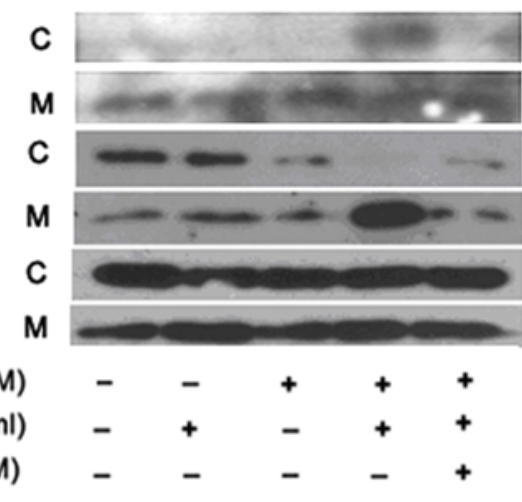

Fluo 4

E

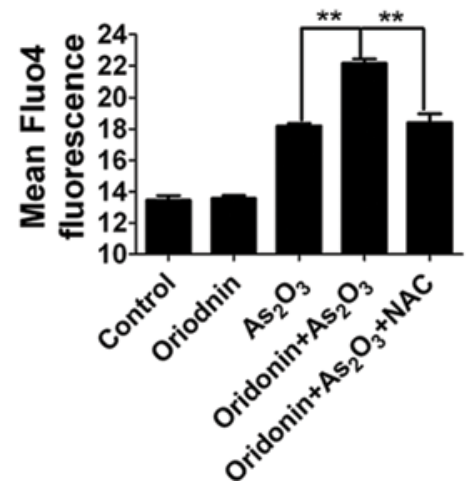

Figure 4. Measurement of mitochondria membrane potential and cytoplasmic calcium. Bel7402 cells were treated with $5 \mu \mathrm{g} / \mathrm{ml}$ oridonin, $8 \mu \mathrm{M}$ As $\mathrm{O}_{3}$, the two-drug combination, or the combination plus $2.5 \mathrm{mM}$ NAC for $20 \mathrm{~h}$. The histograms (A) and mean fluorescence intensity (B) for DiOC6 are shown. Bax and cytochrome C relocation were detected by Western bloting, mitochondrial and cytosol fractions were denoted as $\mathrm{M}$ and $\mathrm{C}$ respectively (C). The histograms (D) and mean fluorescence intensity (E) of Fluo 4 dye was used for labeling intracellular calcium spikes. Representative experiments, $\mathrm{n}=3$, mean $\pm \mathrm{SD}$. ${ }^{*} \mathrm{p}<0.05{ }^{*}{ }^{* *} \mathrm{p}<0.01 ;{ }^{* * * *} \mathrm{p}<0.001$.

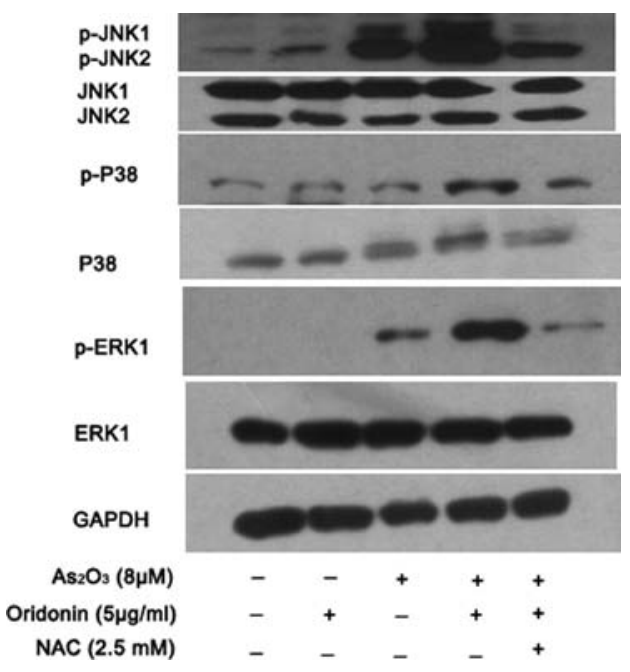

their combination) to tumor bearing mice. These comparable low doses of oridonin and $\mathrm{As}_{2} \mathrm{O}_{3}$ have been used in previous combination therapy studies $(25,26)$. Consistence with the synergistic pro-apoptosis effect in vitro, the two-drug combination displayed significantly enhanced antitumor activity compared with that induced by oridonin or $\mathrm{As}_{2} \mathrm{O}_{3}$ alone (Fig. 7A and $\mathrm{B})$.Besides, the body weight loss of mice in the two-drug combination was not significant when compared with that in $\mathrm{As}_{2} \mathrm{O}_{3}$ single agent treatment (Fig. 7C and D). 
A

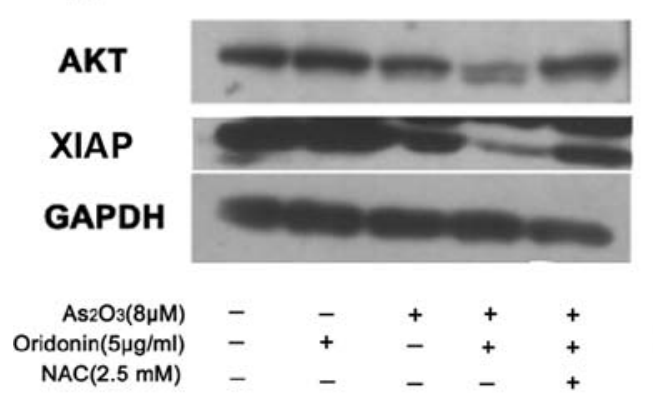

B

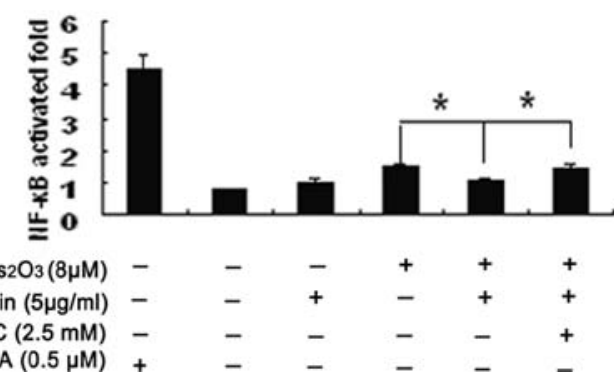

Figure 6. Analysis of Akt and XIAP protein expression (A) and NF- $\mathrm{kB}$ activation (B). Bel7402 cells were treated with $5 \mu \mathrm{g} / \mathrm{ml}$ oridonin, $8 \mu \mathrm{M} \mathrm{As} \mathrm{O}_{3}$, the two-drug combination, or the combination plus $2.5 \mathrm{mM} \mathrm{NAC}$ for $24 \mathrm{~h}$, total cell extracts were subjected to Western bloting for Akt, XIAP and p65. In the luciferase assay, cells were treated as described in Materials and methods, PMA was used as positive control. Representative experiments, $\mathrm{n}=3$, mean $\pm \mathrm{SD}$. ${ }^{*} \mathrm{p}<0.05$.
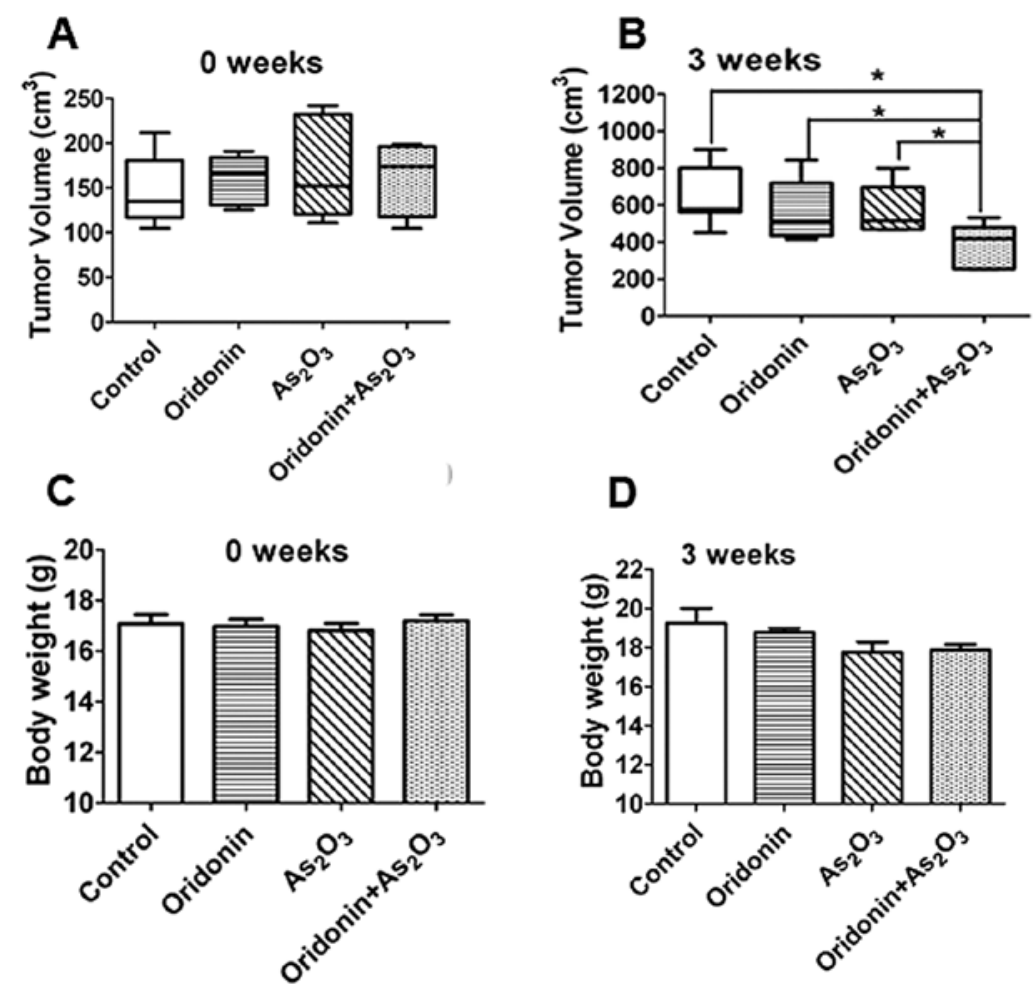

Figure 7. Evaluation of antitumor activity of $\mathrm{As}_{2} \mathrm{O}_{3}$, oridonin or the two-drug combination in murine $\mathrm{HCC}$ model. Hepa1-6 tumor bearing mice received daily injection of $200 \mu 10.9 \% \mathrm{NaCl}$, equal volume of $\mathrm{As}_{2} \mathrm{O}_{3}$ at dose of $3 \mathrm{mg} / \mathrm{kg}$, oridonin at dose of $10 \mathrm{mg} / \mathrm{kg}$ or the combination of the two drugs for 3 weeks. The tumor volume $\left(A\right.$ and $B$ ) and body weight $(C$ and $D)$ at 0 or 3 weeks after administration were measured. Each bar represents the mean \pm SD. ${ }^{*}<<0.05$ ( $n=7$ mice).

\section{Discussion}

The recent phase II study of arsenic trioxide $\left(\mathrm{As}_{2} \mathrm{O}_{3}\right)$ in patients with advanced hepatocellular carcinoma (HCC) showed that $\mathrm{As}_{2} \mathrm{O}_{3}$ was less active than sorafenib, an FDA approved drug for treatment of advanced $\mathrm{HCC}$, and potential cardiotoxicity may hinder its further application (27). Numerous reports have demonstrated that combination treatment with $\mathrm{As}_{2} \mathrm{O}_{3}$ and other therapeutic agents could sensitize leukaemic or solid cancer cells to $\mathrm{As}_{2} \mathrm{O}_{3}$-induced apoptosis and overcome drug resistance in the treatment of various haematopoietic or solid malignancies (28-32). The goal of this study was to develop $\mathrm{As}_{2} \mathrm{O}_{3}$-based effective combination therapy against hepato-cellular carcinoma. We found that oridonin, a diter- penoid isolated from traditional Chinese medicine Rabdosia rubescens, in combination with $\mathrm{As}_{2} \mathrm{O}_{3}$ dramatically enhanced anti-tumor efficacy on human hepatoma cells in vitro and in vivo and this synergistic pro-apoptotic effect resulted from ROS mediated mitochondrial dysfunction and pro-survival signal inhibition.

It is known that $\mathrm{ROS}$ is a critical mediator for $\mathrm{As}_{2} \mathrm{O}_{3}$ induced apoptotic cell death (33), but treatment of Bel7402 cells with a relative low concentration of $\mathrm{As}_{2} \mathrm{O}_{3}(8 \mu \mathrm{M})$ induced no detectable ROS production. Cancer cells seem to have higher level of endogenous oxidative stress compared with normal cells, and the upregulation of antioxidant capacity in adaptation to intrinsic oxidative stress can confer drug resistance (34). In this study, we demonstrated that oridonin at a relative low dose, 
which induced no detectable cells death, could decrease the GSH/GSSG ratio and elicit intracellular ROS level in Bel7402 cells. The increased ROS production induced by comparable low dose of oridonin did not reach the threshold to damage mitochondria leading to apoptosis, but it interrupted tumor intracellular redox status and abrogated the drug resistance of hepatoma cells to $\mathrm{As}_{2} \mathrm{O}_{3}$ treatment.

Accumulation of excessive ROS in leukemia cells in combined treatment with $\mathrm{As}_{2} \mathrm{O}_{3}$ and phytosphingosine led to disruption of the mitochondrial membrane potential, release of apoptotic factors, and resulted in apoptotic cell death (30). In this study, we also provided evidence that the elevation of intracellular ROS level induced by the oridonin- $\mathrm{As}_{2} \mathrm{O}_{3}$ combination treatment is essential for the loss of mitochondrial membrane potential and cytochrome $\mathrm{C}$ release. Complete inhibition of the two-drug combination treatment-induced apoptotic death by antioxidant NAC suggested that the increase of intracellular ROS level is critical for this synergic anti-tumor effect.

The involvement of members of MAPKs in stress induced apoptosis depends on the cell type, stimuli, and the latency of the activation (35). It has been shown that $\mathrm{p} 38$ plays a key role in combination treatment with phytosphingosine and $\mathrm{As}_{2} \mathrm{O}_{3}$ induced cell death in leukemic cells (30). For hepatoma cells, a previous study showed that $\mathrm{As}_{2} \mathrm{O}_{3}$-induced apoptosis is independent of MAPKs signaling pathways in HepG2 cells (36). Consistence with the study in HepG2 cells, p38, ERK1 and JNK $1 / 2$ were stimulated in response to combination treatment with oridonin and $\mathrm{As}_{2} \mathrm{O}_{3}$, but inhibition of their activation using a specific inhibitor failed to protect cells from death induced by the two-drug combination. Thus, MAPKs might not play important roles in executing proapoptotic activity in treatment of hepatoma with $\mathrm{As}_{2} \mathrm{O}_{3}$.

Overactivity of the cell survival signaling pathway appears to be a critical switch in progression and drug resistance of tumor cells (37). The pro-survival molecules such as Akt, XIAP and $\mathrm{NF}-\kappa \mathrm{B}$ were investigated in this study as they are key protecting factors against multiple chemotherapeutic treatment. Of note, single treatment with oridonin or $\mathrm{As}_{2} \mathrm{O}_{3}$ failed to decrease Akt and XIAP expression, but two-drug combination resulted in drastic downregulation of these two factors. Inhibition of $\mathrm{NF}-\kappa \mathrm{B}$ pathway has been reported by other studies and seems to play a role in synergic therapeutic effect induced by combination treatment with $\mathrm{As}_{2} \mathrm{O}_{3}$ and other agents (32). In this study we also found that $\mathrm{NF}-\kappa \mathrm{B}$ activation was significantly inhibited by oridonin and $\mathrm{As}_{2} \mathrm{O}_{3}$ combination treatment. This synergistic suppression of survival signaling factors may also attribute to the increase of intracellular ROS level, because NAC could block this effect.

In conclusion, the present results showed that combination treatment with oridonin and $\mathrm{As}_{2} \mathrm{O}_{3}$ synergize in the induction of apoptosis and antitumor efficacy in hepatocellular carcinoma cells and this synergistic anti-tumor effect results from mitochondrial apoptotic pathway by elevation of intracellular ROS level. This study facilitates the optimization of $\mathrm{As}_{2} \mathrm{O}_{3}$ therapy of $\mathrm{HCC}$ with improved anticancer efficacy and reduced adverse effects.

\section{Acknowledgements}

This study was financially supported by the following grants: Chinese National Nature Sciences Foundation (30500637,
30821006, 50973046), the Doctoral Station Science Foundation from the Chinese Ministry of Education (200802840023), the Jiangsu Provincial Nature Science Foundation (BK2010046, BY2009147), Bureau of Science and Technology of Changzhou (CQ20100009, CN20100016, CZ20100008), Department of Science and Technology of Wujin District, Changzhou (WG2009007, WS201004). The authors have no conflict of interest.

\section{References}

1. Hsu C, Cheng JC and Cheng AL: Recent advances in non-surgical treatment for advanced hepatocellular carcinoma. J Formos Med Assoc 103: 483-495, 2004.

2. Leung TW and Johnson PJ: Systemic therapy for hepatocellular carcinoma. Semin Oncol 28: 514-520, 2001.

3. Yeo W, Mok TS, Zee B, et al: A randomized phase III study of doxorubicin versus cisplatin/interferon alpha-2b/doxorubicin/ fluorouracil (PIAF) combination chemotherapy for unresectable hepatocellular carcinoma. J Natl Cancer Inst 97: 1532-1538, 2005.

4. Douer D and Tallman MS: Arsenic trioxide: new clinical experience with an old medication in hematologic malignancies. J Clin Oncol 23: 2396-2410, 2005.

5. Sanz MA, Grimwade D, Tallman MS, et al: Management of acute promyelocytic leukemia: recommendations from an expert panel on behalf of the European Leukemia Net. Blood 113: 1875-1891, 2009.

6. Tallman MS, Andersen JW, Schiffer CA, et al: All-trans retinoic acid in acute promyelocytic leukemia: long-term outcome and prognostic factor analysis from the North American Intergroup protocol. Blood 100: 4298-4302, 2002.

7. Kito M, Akao Y, Ohishi N, Yagi K and Nozawa Y: Arsenic trioxide-induced apoptosis and its enhancement by buthionine sulfoximine in hepatocellular carcinoma cell lines. Biochem Biophys Res Commun 291: 861-867, 2002.

8. Zhang TC, Cao EH, Li JF, Ma W and Qin JF: Induction of apoptosis and inhibition of human gastric cancer MGC-803 cell growth by arsenic trioxide. Eur J Cancer 35: 1258-1263, 1999.

9. Shen ZY, Zhang Y, Chen JY, et al: Intratumoral injection of arsenic to enhance antitumor efficacy in human esophageal carcinoma cell xenografts. Oncol Rep 11: 155-159, 2004.

10. Maeda $\mathrm{H}$, Hori $\mathrm{S}$, Nishitoh $\mathrm{H}$, et al: Tumor growth inhibition by arsenic trioxide $\left(\mathrm{As}_{2} \mathrm{O}_{3}\right)$ in the orthotopic metastasis model of androgen-independent prostate cancer. Cancer Res 61: 5432-5440, 2001.

11. Nakagawa Y,Akao Y, Morikawa H, et al: Arsenic trioxide-induced apoptosis through oxidative stress in cells of colon cancer cell lines. Life Sci 70: 2253-2269, 2002.

12. Lin $\mathrm{CC}$, Hsu C, Hsu CH, Hsu WL, Cheng AL and Yang $\mathrm{CH}$ : Arsenic trioxide in patients with hepatocellular carcinoma: a phase II trial. Invest New Drugs 25: 77-84, 2007.

13. Oketani M, Kohara K, Tuvdendorj D, et al: Inhibition by arsenic trioxide of human hepatoma cell growth. Cancer Lett 183: 147-153, 2002.

14. Panthel K, Meinel KM, Sevil Domenech VE, et al: Prophylactic anti-tumor immunity against a murine fibrosarcoma triggered by the Salmonella type III secretion system. Microbes Infect 8: 2539-2546, 2006.

15. Huang J, Wu L, Tashiro S, Onodera S and Ikejima T: Reactive oxygen species mediate oridonin-induced HepG2 apoptosis through p53, MAPK, and mitochondrial signaling pathways. J Pharmacol Sci 107: 370-379, 2008.

16. Jin HO, Yoon SI, Seo SK, et al: Synergistic induction of apoptosis by sulindac and arsenic trioxide in human lung cancer A549 cells via reactive oxygen species-dependent down-regulation of survivin. Biochem Pharmacol 72: 1228-1236, 2006.

17. Kang YH, Yi MJ, Kim MJ, et al: Caspase-independent cell death by arsenic trioxide in human cervical cancer cells: reactive oxygen species-mediated poly(ADP-ribose) polymerase-1 activation signals apoptosis-inducing factor release from mitochondria. Cancer Res 64: 8960-8967, 2004.

18. Cao L, Du P, Jiang SH, Jin GH, Huang QL and Hua ZC: Enhancement of antitumor properties of TRAIL by targeted delivery to the tumor neovasculature. Mol Cancer Ther 7: 851-861, 2008. 
19. Chen G, Wei DP, Jia LJ, et al: Oral delivery of tumor-targeting Salmonella exhibits promising therapeutic efficacy and low toxicity. Cancer Sci 100: 2437-2443, 2009.

20. Wang IK, Lin-Shiau SY and Lin JK: Induction of apoptosis by apigenin and related flavonoids through cytochrome c release and activation of caspase-9 and caspase-3 in leukaemia HL-60 cells. Eur J Cancer 35: 1517-1525, 1999.

21. Bratton SB, Lau SS and Monks TJ: The putative benzene metabolite 2,3,5-tris(glutathion-S-yl)hydroquinone depletes glutathione, stimulates sphingomyelin turnover, and induces apoptosis in HL-60 cells. Chem Res Toxicol 13: 550-556, 2000.

22. Rogalska A, Koceva-Chyla A and Jozwiak Z: Aclarubicin-induced ROS generation and collapse of mitochondrial membrane potential in human cancer cell lines. Chem Biol Interact 176: 58-70, 2008

23. Cartron PF, Bellot G, Oliver L, Grandier-Vazeille X, Manon S and Vallette FM: Bax inserts into the mitochondrial outer membrane by different mechanisms. FEBS Lett 582: 3045-3051, 2008.

24. Su CC, Lin JG, Li TM, et al: Curcumin-induced apoptosis of human colon cancer colo 205 cells through the production of ROS, $\mathrm{Ca}^{2+}$ and the activation of caspase-3. Anticancer Res 26: 4379-4389, 2006.

25. Gao FH, $\mathrm{Hu} \mathrm{XH}, \mathrm{Li} \mathrm{W}$, et al: Oridonin induces apoptosis and senescence in colorectal cancer cells by increasing histone hyperacetylation and regulation of p16, p21, p27 and c-myc. BMC Cancer 10: 610, 2010.

26. Russmann H, Igwe EI, Sauer J, Hardt WD, Bubert A and Geginat G: Protection against murine listeriosis by oral vaccination with recombinant Salmonella expressing hybrid Yersinia type III proteins. J Immunol 167: 357-365, 2001.

27. Rodgers HKS, Malani A, Willis M and Markowitz A: A phase II study of arsenic trioxide (ATO) in patients with advanced hepatocellular carcinoma (HCC). J Clin Oncol (Abst) 28: e14686, 2010.

28. Kim HR, Kim EJ, Yang SH, et al: Combination treatment with arsenic trioxide and sulindac augments their apoptotic potentia in lung cancer cells through activation of caspase cascade and mitochondrial dysfunction. Int J Oncol 28: 1401-1408, 2006.
29. Park JH, Kim EJ, Jang HY, et al: Combination treatment with arsenic trioxide and sulindac enhances apoptotic cell death in lung cancer cells via activation of oxidative stress and mitogenactivated protein kinases. Oncol Rep 20: 379-384, 2008.

30. Park MT, Kang YH, Park IC, et al: Combination treatment with arsenic trioxide and phytosphingosine enhances apoptotic cell death in arsenic trioxide-resistant cancer cells. Mol Cancer Ther 6: 82-92, 2007

31. Sanchez Y, Amran D, Fernandez C, De Blas E and Aller P: Genistein selectively potentiates arsenic trioxide-induced apoptosis in human leukemia cells via reactive oxygen species generation and activation of reactive oxygen species-inducible protein kinases (p38-MAPK, AMPK). Int J Cancer 123: 1205-1214, 2008.

32. Yi J, Yang J, He R, et al: Emodin enhances arsenic trioxide-induced apoptosis via generation of reactive oxygen species and inhibition of survival signaling. Cancer Res 64: 108-116, 2004.

33. Li JX, Shen YQ, Cai BZ, et al: Arsenic trioxide induces the apop-tosis in vascular smooth muscle cells via increasing intracellular calcium and ROS formation. Mol Biol Rep 37: 1569-1576, 2010.

34. Trachootham D, Alexandre J and Huang P: Targeting cancer cells by ROS-mediated mechanisms: a radical therapeutic approach? Nat Rev Drug Discov 8: 579-591, 2009.

35. Wada T and Penninger JM: Mitogen-activated protein kinases in apoptosis regulation. Oncogene 23: 2838-2849, 2004.

36. Kang SH, Song JH, Kang HK, et al: Arsenic trioxide-induced apoptosis is independent of stress-responsive signaling pathways but sensitive to inhibition of inducible nitric oxide synthase in HepG2 cells. Exp Mol Med 35: 83-90, 2003.

37. Mollinedo F: Survival and apoptotic signals in the action of microtubule-targeting antitumor drugs. Drugs 8: 127-143, 2005. 